\title{
Schwarzt'ın Sosyal Değerler Modelindeki Bireysel Değerlere Göre Tüketicilerin Çevreye Duyarlı Tüketim Davranışlarının İsimsel Lojistik Regresyon Analizi İle İncelenmesi
}

\author{
Tahir BENLI ${ }^{1}$ ve Yıldıray KIZGIN²
}

$\ddot{O} z$

Tüm dünyanın yaşadığı çevre sorunlarının anlaşılması ekolojik bir bakış açısı gerektirse de bu sorunların yaşanmasındaki insan etkisi dikkate alındığında, davranışlar üzerinde etkisi olan değer yapılarının incelenmesi gereklidir. Bu kapsamda, bu çalışmada, Schwartz Değerler Ölçeği” olarak bilinen ölçeğin ikinci ekseni olan bireysel değerler boyutundaki "Kendini Aşma" ve "Kendini geliştirme" değer öbekleri kapsamındaki değer yapılarının; Tasarruflu tüketim, Geri dönüşüme destek verme, Çevreci satın alma davranış eğilimi sınıflarındaki Çevreye duyarlı tüketim davranış eğilimlerine göre sınıflandırılması amaçlanmaktadır. Bu amaçla, "Evrenselcilik" , "İyilikseverlik", "Güç", "Başarı" ve "Hazcılık" değer yapılarının çevreci davranış tipleri üzerindeki etkisinin anlaşılması amacıyla ABD'deki bir üniversite öğrencilerinden kolayda örnekleme yöntemiyle toplanmış 203 veriye İsimsel Lojistik Regresyon analizi uygulanmıştır. Elde edilen model ile tasarruflu tüketim eğilimli bireylerde, çevreci satınalma eğilimli bireylere göre; evrenselcilik ve başarı değerlerinin negatif yönlü; iyilikseverlik değerinin ise pozitif ayrıştığ1; geri dönüşüm desteği eğilimli bireyler ile tasarruflu tüketim eğilimli bireylerin ise bu değer yapıları açısından ayrışmadıkları anlaşılmıştır.

Anabtar Kelimeler: Değerler, Schwartz’ın sosyal değerler modeli, Genç bireyler, Sürdürülebilir tüketim davranışı, İsimsel Lojistik Regresyon Analizi

Investigation of Consumers Sustainable Consumption Behaviors by Multinominal Logistic Regression Analysis According To Individual Values Where Schwartz's Social Values Model

\section{Abstract}

Although it requires an ecological perspective to understand the environmental problems of the whole world, it is necessary to examine the value structures that have an impact on behaviors considering the impact of the human in these problems. In this study, the value structures "Self-transcendence" and "Self-enhancement" value groups in the dimension of individual values, which are the second axis of the scale known as the Schwartz Values Scale; Environmentally conscious consumption behaviors tendencies according to as Conservative consumption, Recycling supporting and Environmental purchasing behaviors is aimed to be classified. In order to understand the effect of value structures such as "universalism", "benevolence", "power", "achievement" and "hedonism" on environmental behavior types; A total of 203 data were collected from a university student in the USA using Multinominal Logistic Regression Analysis. According to obtained the model, the individuals who are in the tendency of Conservative consumption according to the individuals who are in the tendency Environmental purchasing behaviors, about values "universalism" and "success" impact on negative; but value "benevolence" as positive; however, it is understood that individuals who are tendency to recycling support and individuals who have a tendency to save consumption do not differ in terms of their value structures.

Key Words: Values, Schwartz's social values, young people, Sustainable consumption behavior Multinominal Logistics Regression Analysis

Atıf İçin / Please Cite As:

Benli, T. ve Kızgın, Y. (2020). Schwarzt'ın sosyal değerler modelindeki bireysel değerlere göre tüketicilerin çevreye duyarlı tüketim davranışlarının isimsel lojistik regresyon analizi ile incelenmesi. Manas Sosyal Araştırmalar Dergisi, 9(2), 995-1009.

Geliş Tarihi / Received Date: 29.01.2019

Kabul Tarihi / Accepted Date: 04.12.2019

${ }^{1}$ Dr. Öğr. - Kastamonu Üniversitesi İIBF, tbenli@yahoo.com - ORCID: 0000-0001-6380-3562

2 Doç. Dr. - Muğla Sttkı Koçman Üniversitesi İİBF, ykizgin@mu.edu.tr - ORCID: 0000-0002-7844-052X 


\section{Giriş}

Günümüzde toplumsal ihtiyaçların karşılanması ile birlikte gelecek nesillerin ihtiyaçlarının da karşılanması düşüncesini ele alan "sürdürülebilir gelişme düşüncesi", tüm toplumların geliştirmeye, yaygınlaştırmaya ve sistemleştirmeye çalıştıkları çok önemli bir misyondur.

Sürdürülebilirlik için ciddi bir tehdit oluşturan küresel ısınma, kentsel hava kirliliği, su kıtlığı, çevresel gürültü ve biyoçeşitlilik kayb1 gibi çevresel problemlerin çoğunun insan davranışlarına dayandığ1 görülmektedir (Gardner ve Stern, 2002; Steg ve Vlek, 2009). Her ne kadar bu tür sorunların ekolojik tabanlı çalışmalarda ele alınması gerekliliği düşünülse de sorunların yaşanmasında insan ve tüketim ilişkisinin etkisi bulunduğundan sorunların çevresel etkilerini azaltmak için insan davranışlarının değiştirilerek yönetilmesi gerekliliği ortaya çıkmıştır. Bu durum toplumların sürdürülebilir tüketim davranışlarının anlaşılmasını, benimsenmesini ve yaygınlaştırılmasını gerektirmektedir. $\mathrm{Bu}$ ise insan davranışını belirleyen etkenlerin araştırılması ve anlaşılması ile mümkündür.

Bu bağlamda bireysel değerler, yaşamın tüm alanına ilişkin davranışlarda olduğu gibi, bireylerin tüketici olarak gerçekleştirdikleri davranışlar üzerinde de etkili olmaktadır (Karalar ve Kiracı, 2010, s. 81). Değerler, hangi toplumsal davranışın iyi, doğru ve arzulanan olduğunu belirten, paylaşılan ölçüt veya fikirler olup; davranışların esin kaynağ1 olduğu bilinmektedir (Özkalp, 2005, s. 100; Doğan, 2002, s. 341). Değerler ve kültür, çevresel sorunlara bakış açımızı sınırlandıran bir gözlük gibidir. Aynı zamanda bizi ilgilendiren bu tür sorunların anlaşılması ve çözülmesinde etkili olacak çözümleri üretmemizi de sağlar. Çevre programlarını yapılandırmak, sürdürülebilir çevre anlayışını geliştirebilmek için deneysel olarak test edilmiş psikolojik teori ve ilkelerin yer aldığı çalışmaların kültürler arası olarak test edilmesi gereklidir (Schultz vd., 2005, s. 473). Tüketici değerlerinin iyi anlaşılmasıyla, tüketici davranışlarının daha iyi tahminlenmesi ve kontrol edilebilmesinin çok daha mümkün olacağı düşünülmektedir.

Bu çalışmada, üniversite öğrencilerinin çevreci davranışlarının Schwartz, (1992; 1994) tarafından geliştirilen "Schwartz Değerler Ölçeği-SVS" olarak bilinen ve ölçeğin ikinci ekseni olan bireysel değerler boyutundaki "kendini aşma" (self-transcendence) ve "kendini geliştirme"(self enhancement) değer öbekleri ile Dunlap ve Van Liere (1978) tarafindan geliştirilen "Yeni Ekolojik Paradigma Ölçeği"(New Environmental Paradigm Scale) kapsamındaki çevreye duyarlı tüketim davranışı "tasarruflu tüketim", "geri dönüşüme destek verme" ve "çevreci satınalma" boyutlarına göre sınıflandırılması amaçlanmaktadır. Bu sayede değer tutumu bilinen bir kişinin ne şekilde çevreye duyarlı bir tüketim davranışı göstereceğini anlamak veya çevreci davranış eğilimleri bilinen üniversite öğrencilerinin hangi değer yapılarında ayrışacağını anlamak mümkün olabilecektir.

\section{Kuramsal Çerçeve}

\section{Değerler ve Schwartz'in Değerler Teorisi}

Yazına bakıldığında değere ilişkin pek çok tanım göze çarpmaktadır. Kluckhohn (1951) değerleri; arzularda değil, arzu edilebilende yer alan; bir başka deyişle sadece istediğimiz bir şey değil, kendimiz ve başkaları için istemenin doğru ve uygun olduğunu hissettiğimiz şeyler olarak tanımlamaktadır. Ona göre insani değerler, insan yaşamındaki önemi değişen ve istenen hedefler olarak tanımlanmaktadır. Rokeach (1973) değerleri, rehber ilkeler, önemli yaşam hedefleri veya standartlar olarak tanımlamış, sosyal davranışları ve ideolojileri belirlediklerini varsaymıştır. Ona göre değerlerin en önemli özelliği, davranışsal seçenekler üzerinde ölçülebilir bir etkiye sahip olmalarıdır. Schwartz ve Bilsky (1987) değerleri, bireyin amaçlarına ulaşmadaki davranışlarıyla ilişkili inançlar olarak tanımlamakta ve ayııca değerlerin önemlerine göre derecelendirilebileceğini belirtmektedirler. Yani değerler her insan için önemli ve bir insanı diğerlerinden farklılaştıran etkenlerdir. Schwartz $(1992,1994)$ değerlerin, bireylerin, grupların ve toplumların hakkında bilgi edinilmesini sağladığını ifade etmektedir. Buradan değerlerin sadece bireyleri diğer bireylerden farklılaştıran etkenler olmadığı, aynı zamanda grupları ve toplumları da diğer grup ve toplumlardan ayrıştırdığı sonucu çıkarılabilir.

Değerler kişinin duygularıyla bağlantılı inançlardır. Değerler arzulanan hedeflere ulaşmak için davranışı yönlendiren belli bir standarda göre, görece önemli davranışa yol açan ilkelerdir (Schwartz, 2009). Değerler, bireyin gelişim sürecinde oluşmaktadır. Bir başka deyişle, bireyler değerleriyle birlikte doğmamaktadırlar (Evans, Jamal ve Foxall, 2006, s. 22). Bireylerin değerlerinin oluşmasinda içinde yaşadıkları toplumun değerleri, yani kültürel değerler de etkili olmaktadır (Hofstede, 1980 den aktaran Özgür, 2013, s. 46). Psikologlar, bir çocuğun 10 yaşına kadar temel değerlerin büyük bir çoğunluğunu edindiğini ileri sürmektedirler (Hofstede, 1991, s. 8). Değişen toplumsal değişkenlere bağlı olarak 
toplumların yaşantısı ve yeni düzenlemelere uyumları bireysel değerler ile yakından ilişkilidir. Sosyal politikaların başarısının değerlendirilmesi, değerlerin ve etkilerinin detaylı bir şekilde araştırılmasını gerektirmektedir (Kağıtçıbaşı, 1990). Değerlerin çocukluk yıllarından itibaren belirlenmesi, çocukların daha sonraki yıllarda sahip oldukları değerlerin tahminlenmesine yardımcı olacaktır. Diğer bir deyişle, erken yıllardan itibaren değerlerin belirlenmesi, daha sonraki yıllardaki değer değişiminin yönünün görülmesine olanak sağlayacaktır (Kapıkıran ve Gündoğan, 2016, s. 125).

Değerlerle ilgili yazına bakıldığında, aralarında Rokeach 'ın Değerler Sistemi (RVS), Değerler ve Yaşam Biçimi Sistemi (VALS), Kahle 'nin Değerler Listesi (LOV), Hofstede 'nin Kültürel Değer Kuramı, Schwartz 'ın Değerler Listesi (SVS) ve Stern 'in Değer Temelli Kuramının (VBT) yer aldığı pek çok çalışmanın olduğu görülmektedir. Bu çalışmada Schwartz 'in değer kuramına ilişkin SVS ölçeği kullanıldığından bu kurama ait bilgilere yer verilmektedir.

Schwartz ve Bilsky $(1987 ;$ 1990) Rokeach'ın değer listesinde bulunan 36 değeri kullanılarak, değerler listesi geliştirme girişimlerinin ilk adımlarını atmışlardır. Daha sonra Schwartz 1992 yllında gerçekleştirdiği bir çalışmada, Rokeach'ın 36 değerden oluşan listesini geliştirerek evrensel nitelik taşıdığı düşünülen 56 değeri, 10 değer öbeğinde toplamıştır. Geliştirilen değer ölçeğinin 54 farklı ülkede yürütülen çalışma sonrasında elde edilmesi, kültürlerarası geçerliğinin saptanmasına da olanak sağlamıştır. Ayrıca, Schwartz (1992), birbiriyle çelişen değerleri "Değişime açılık / Tutucu yaklaşım (Opennes to change / Conservation)" ve "Kendini aşma/ Kendini geliştirme (Self-transcendence /Self-enhancement)" olarak iki boyuta ayırmıstır.

"Kendini aşma", bencil amaçların diğer insanlar ya da doğa lehine feragat edilmesi anlamında "evrenselcilik" ve "iyilikseverlik" davranışlarını içerir. "Kendini geliştirme" ise; "güç", "başarı" ve "hazcıllk" gibi egoist davranışlara yönelik motivasyonları içerir. "Tutuculuk" bireylerin yakın oldukları kişilerle, kurumlarla ve geleneklerle olan ilişkilerindeki süreklilik ve belirliliğin sürmesine olanak sağlayan "geleneksellik", "uyum" ve "güvenlik" değer tiplerini içermektedir. "Değişime açıklık" ise, insanları duygusal ve entelektüellerini takip etmeye yönlendiren "özyönelim" ve "uyarrlım" değer tiplerinden oluşmaktadır. Schwartz'n değer kuramı, belirlenen 10 değer tipleri arasındaki dinamik ilişkileri belirlemeye yönelik olarak biçimlendirilmiştir. Değer tiplerinin, güdüsel amaçları kapsamında, birbirleriyle uyum ya da çelişki içinde olabilecek nitelikte oldukları görülür (Karalar ve Kirac1, 2010, s. 84).

\section{Kişisel Değerler ve Sürdürülebilir Tüketim Davranış1}

Çevresel davranış ve tutumların insani değerlerle ilgili olduğu konusunu inceleyen çalışmalara sıklıkla rastlanabilir (Dunlap, Grieneeks ve Rokeach, 1983; Karp, 1996; Schultz ve Zelezny, 1999; Stern, 2000). Özellikle bireysel değerlerle sürdürülebilir tüketim davranışları arasındaki ilişkiyi inceleyen çalışmalarda, Rokeach'ın değer listesini (Dunlap vd., 1983), Kahle'nin değer listesini (McCarty ve Shrum, 1994), Stern vd.'nin değer temelli kuramını (Bagozzi ve Dabholkar, 1994; Corraliza ve Berenguer, 2000) kullanan çalışmalar olmasina rağmen, Schwartz 'in Değerler Listesinin (SVS) (Grunert ve Juhl, 1995; Karp, 1996; Thøgersen ve Ölander, 2002; Thøgersen ve Grunert-Beckmann, 1997) kullanıldığı çalışmaların oldukça yaygin olduğu görülmektedir.

Karp (1996) tarafindan yapılan bir çalışmada, geri dönüşüme destek davranışı, tüketici davranışı ve çevrenin korunması için politik davranışlar gibi davranışların Schwartz 'in değerler kuramıyla ilgili olduğu bulunurken; Stern, Dietz, Abel, Guagnano ve Kalof (1999) yaptığı bir çalışmada, Schwartz'ın (1992) değer listesinde yer alan Kendini aşma değer öbeğinin, çevreci tüketim davranışının ortaya çıkmasında olumlu yönde etkisinin olduğunu vurgulamışır.

Schwartz’ın (1992) değer ölçeği kullanılarak, değerler ve çevreci davranışlar arasındaki ilişkiyi inceleyen çalışmalara bakıldığında, çoğunlukla söz konusu ölçeğin Kendini aşma ve Kendini geliştirme boyutları ele alınmaktadır (Schultz vd., 2005, s. 459). Bunun nedeni, daha önce yapilan çalışmalarda (Stern, Dietz ve Guagnano, 1998; Stern ve Dietz, 1994; Karp, 1996) Schwartz'ın Kendini geliştirme ve kendini aşma değeri boyutları ile çevre dostu davranış arasında istatistiksel bir ilişki olduğunun belirlenmiş olmasidır.

Bu doğrultuda, Karp'ın (1996) çalışmasında, kendini aşma değer öbeğinin çevreci davranışlarla pozitif yönlü; kendini geliştirme boyutunun ise hem çevreci tutumlarla hem de çevreci davranışlarla negatif yönlü ilişskili olduğu belirlenmiştir (Schultz vd., 2005, s. 469). Thøgersen ve Ölander (2002) tarafindan yapılan bir araştırmada, kendini aşma boyutunda yer alan "evrensellik" değer tipinin sürdürülebilir tüketim 
davranışıyla pozitif yönde anlamlı ilişkisinin olduğu belirlenmiştir. Bunun yanında, "iyilikseverlik" ve "hazcılık" değer tipinin sürdürülebilir tüketim davranışılla negatif yönlü ilişkili olduğu saptanmıştır. Nordlund ve Garvill (2002) tarafindan yapılan bir araştırmada, Kendini aşma değer boyutunun çevreci davranışla arasında pozitif yönlü, Kendini geliştirme değer boyutunun çevreci davranışla arasında negatif yönlü bir ilişki olduğu belirlenmiştir. Yine Nordlund ve Garvill (2003) tarafindan, kişisel otomobil kullanımını azaltma davranışı ile kişisel değerler ve tutumlar arasında; Kendini aşma değer öbeği ile kişisel otomobil kullanımını azaltma davranışı arasında düşük düzeyde fakat pozitif yönlü bir ilişki olduğu belirlenmiştir. Bir başka çalış̧mada ise, Kendini geliştirme boyutunun bireysel enerji tüketim davranışı ile negatif yönlü ilişkisinin olduğu belirlenmiştir (Poortinga, Steg ve Vlek, 2004, s. 88).

Kültürlerarası karşılaştırmalı araştırmalarda Schwartz 'ın değerler modelinin evrensel olarak geçerli olup olmadığ1 birçok çalışmanın konusunu oluşturmuştur (Schwartz ve Bardi, 2001; Schwartz ve Sagie, 2000). Bu kapsamda verilecek örneklerden birisi Schultz vd. (2005) tarafından Brezilya, Çek Cumhuriyeti, Almanya, Hindistan, Yeni Zelanda ve Rusya 'da yapılan çalışmalarda; değerler ve tutumlar arasındaki ilişkinin kültürlerarası genellenebilirliğine ve çevresel kaygının yapısına güçlü bir destek olduğuna işaret edilmektedir. Değerler ve çevresel davranış arasındaki ilişki kapsamında analizler, sadece "Kendini aşma" değer öbeğinde Schwartz (1977) Norm-Aktivasyonu Kuramı kanıtlarını gösterirken; "Kendini geliştirme" sonuçları sürekli olarak negatif bir ilişki göstermektedir.

Şener ve Hazer (2007) ise Türkiye'deki kadınların değerleri ve sürdürülebilir tüketim davranışlarını incelendikleri çalışmalarında; kadınların "evrenselcilik" ve "iyilikseverlik" değerlerine "başarı", "güç" ve "hazcllğga" göre daha fazla önem verdiklerini; sahip olunan değerlerin sadece insanların günlük yaşantılarını değil, çevreye duyarlı tüketim alışkanlıklarını da etkilediğini ifade ederek, Türk kadınının kültürel ve insani değerlerini incelemişlerdir.

Tüketicilerin tüketim anlayış ve tercihlerinin çevre konularının anlaşılması ve çevre problemlerinin çözümünde etkisi olduğu bilinen ve dikkate alınması gereken önemli bir konudur. Belirli değer tiplerinin sürdürülebilir tüketim davranışının, çevreci davranışlar ve tüketim davranışları ile ilişkili olduğunun anlaşılmasına karşın; ilişkilerin güçlü olmadığı; bireyci bir toplumda yetişmiş ve zevkine düşkün olan bir bireyin davranışlarının, grupçu değerlerin yüksek olduğu başka bir toplumda doğru olmayabileceği unutulmamalıdır. Poortinga vd. (2004) çalışmasında, değerler gibi sadece tutumsal değişkenlerin kullanılarak, tüm çevresel davranış türlerinin açıklanmasının çok sınırlı kalabileceğini vurgulamaktadır.

\section{Yöntem}

Çalışmanın bu kısmında, amaç, önem, veri toplama yöntemi ve analizi, bulguları ve sonuçları hakkında bilgiler verilecektir.

\section{Amaç ve Önem}

Bu çalışmada, üniversite öğrencilerinin Dunlap ve Van Liere (1978) tarafından geliştirilen Yeni Ekolojik Paradigma Ölçeği kapsamındaki; Çevreye duyarlı tüketim davranışlarının kendi içinde "tasarruflu tüketim", "geri dönüşüme destek verme" ve "çevreci satın alma" davranışlarına yönelik sınıfsal farklılıkların Schwartz 'in değerler modelindeki bireysel değerler olarak da bilinen "Kendini aşma" değer öbeği içindeki, "evrenselcilik" ve "iyilikseverlik" değerleri ile "kendini geliştirme"” değer öbeği kapsamında; "başarı", "güç" ve "hazcılık" değerlerine göre sınıflandırılması amaçlanmıştır. İsimsel Lojistik Regresyon analizi yardımıyla hangi çevreci eğilimlerin hangi değer yapılarında ayıışı̆̆ının anlaşılması; hangi çevreci eğlim yapısının hangi değer tipinde daha baskın olup olmadığının belirlenmesi bu çalışmanın diğer amacını oluşturmaktadır.

Bu çalışmanın bulguları yardımıyla, Schwartz 'in değerler modelinin evrensel anlamda geçerliliğinin anlaşılması yanında; farklı kültürlerin kültürlerarası karşılaştırmalara konu olacak değer yapılarının ve çevreci davranışlarının da anlaşılmasına yardımcı olunması düşünülmektedir.

\section{Evren ve Örneklem}

Araştırmanın evrenini Amerika Birleşik Devletleri Montana Eyaleti 'ndeki üniversite öğrencileri, örneklemini ise üniversite öğrencileri arasından gönüllülük esası ve kolayda örnekleme yöntemi ile ulaşılan 274 öğrenci oluşturmaktadır. 


\section{Veri Toplama}

Çalışma verileri, yazarların 2013 yllındaki ziyaretleri sırasında ABD 'nin Montana eyaletindeki üniversite öğrencilerinden Eylül - Kasım aralığında toplanmıştır. Kampüs içinde ve şehirde ankete katılma isteğini kabul eden 274 öğrenciden yüz yüze anket yoluyla toplanan veriler; elden geçirilmiş, cevap vermeme ve yanlış cevap verme gibi nedenlerin yanında, aykırı (outliers) veri niteliğindeki bazı anket verileri analize alınmamış, toplam 203 kişinin anket verileri değerlendirilmiştir.

\section{Anket Tasarımı}

Daha önce (Stern vd., 1998; Stern ve Dietz, 1994; Karp, 1996; Thøgersen ve Ölander, 2002; Nordlund ve Garvill, 2002; Nordlund ve Garvill, 2003; Şener ve Hazer, 2007) tarafindan yapilan çalışmalarda; Schwartz 'in Değer Kuramındaki değer ölçeğinde (SVS); "Kendini aşma" değeri öbeğindeki "evrenselcilik", "iyilikseverlik" değerleri ve "Kendini geliştirme" değer öbeğindeki; "başarı", "güç" ve "hazcıllk" değer yapıları ile sürdürülebilir tüketim davranışları arasında istatistiksel bir ilişki olduğunu belirlemiş olmalarından dolayı "Kendini aşma" değer öbeğindeki onüç (13) ve "Kendini geliştirme" değer öbeğindeki onbir (11) ölçek maddesi olmak üzere toplam yirmidört (24) ölçek maddesi dikkate alınmıştır. Cevaplar beşli(5) Likert ölçeği kapsamında; 1=Tamamen önemsiz, 2= Önemsiz 3= Ne önemli ne önemsiz 4=Önemli ve 5=Tamamen önemli, şeklinde alınmıştır.

Çevresel tutumu ölçmek üzere ise Dunlap ve Van Liere (1978) tarafindan geliştirilen Yeni Ekolojik Paradigma Ölçeği tercih edilmiştir. Çevresel tutumları ayrıştırmak amacıyla; Tasarruflu tüketim için üç(3), Geri dönüşüme destek verme için üç(3), Çevreci satın alma davranışı tutumu için dokuz(9) madde olmak üzere toplamda onbeş (15) madde bulunmaktadır. Bu ölçeğin cevapları da; yine beşli(5) bir Likert ölçeği kapsamında toplanmış olup; 1=Tamamen katılmıyorum, 2=Katılmıyorum 3= Ne önemli ne önemsiz, 4=Katıllyorum ve 5=Tamamen katılıyorum, şeklinde alınmıştır.

Katıllmcıların "Kendini aşma" değeri öbeğindeki "evrenselcilik" ve "iyilikseverlik" değerleri ile "Kendini geliştirme" değer öbeğindeki; "başarı", "güç" ve "hazcılık" değer yapiları skorlarının aritmetik ortalamaları analize alınmışır. Diğer taraftan katılımcıların çevresel tutumlarının anlaşılması amacıyla Dunlap ve Van Liere (1978) tarafından geliştirilen Yeni Ekolojik Paradigma Ölçeğindeki maddelerin "Tasarruflu tüketim", "Geri dönüşüme destek", ve "Çevreci satın alma" davranışı tutumuna yönelik baskın çevreci davranış tiplerine göre ayrıştırılması için her grup skorlarının aritmetik ortalaması alınmış ve en yüksek skorlu ortalama kişinin çevreci davranışının belirlenmesinde belirleyici olmuştur. Hiçbir çevreci davranışı baskın bir eğilim olarak göstermeyen katılımcılar ile aynı anda iki veya üç farklı çevreci eğilimde olduğu belirlenen katılımcıların cevapları analiz kapsamı dışına alınarak çevreci eğilim tiplerinin doğru bir şekilde sınıflandırılması amaçlanmıştır.

\section{Verilerin Analizi}

Araştırma ölçeğinin güvenilirliğinin belirlenmesi amacıyla kullanılan içsel tutarlılık ölçütü olan Cronbach Alpha değerleri; Tablo 1'de verilmiştir.

Tablo 1. Değer Tiplerinin ve Sürdürülebilir Cevreci Davranıslarn Güvenilirlik, Standart Sapma ve Ortalamalar

\begin{tabular}{|l|c|c|c|c|}
\hline \multicolumn{1}{|c|}{ Değerler/SürdürülebilirÇevreci Davtanışlatı } & Maddesay1si & Cronbach'sAlpha & Ort. & Std. Sap. \\
\hline Evrenselcilik & 8 & 0,755 & 4,35 & 3,61 \\
\hline Iyilikseverlik & 5 & 0,762 & 4,55 & 2,57 \\
\hline Kendini aşma & $\mathbf{1 3}$ & $\mathbf{0 , 7 6 4}$ & $\mathbf{4 , 4 5}$ & $\mathbf{2 , 4 7}$ \\
\hline Güç & 4 & 0,805 & 2,87 & 3,23 \\
\hline Başarı & 4 & 0,654 & 4,36 & 1,88 \\
\hline Hazcıllk & 3 & 0,811 & 4,19 & 2,04 \\
\hline Kendini Geliştirme & $\mathbf{1 1}$ & $\mathbf{0 , 8 2 9}$ & $\mathbf{3 , 8 1}$ & $\mathbf{1 , 8 8}$ \\
\hline Tasarruflu tüketim & 3 & 0,701 & 3,96 & 0,49 \\
\hline Geri dönüşüme destek verme & 3 & 0,808 & 3,63 & 1,03 \\
\hline Çevreci satınalma davraniş1 & 9 & 0,838 & 3,48 & 0,66 \\
\hline
\end{tabular}

"Kendini aşma" değeri öbeğindeki "evrenselcilik" ve "iyilikseverlik" değerleri ile "Kendini geliştirme" değer öbeğindeki; "başarı", "güç" ve "hazcllık" değer yapılarının hangi sürdürülebilir tüketim davranışında (çevre dostu davranış) belirgin bir şekilde ayrıştığının anlaşılması; değişkenler arasındaki ilişskilerin gücünün ölçülmesi ve bağımsız değişkenlerin oransal yüzdelerinin saptanması amacıyla İsimsel (Multinominal) Lojistik Regresyon Analizi uygulanmıştır. Bu sayede değer tutumu bilinen bir kişinin hangi çevreci davranış 
eğiliminde olabileceğini anlamak ve bu konuda daha önceki kültürlerarası yapılan çalışmalardaki bulgular ile karş1laştırmak mümkün olabilecektir.

\section{Ísimsel (Multinominal) Lojistik Regresyon Analizi}

Değişkenler arası ilişskileri incelemede en çok kullanılan istatistik yöntemlerinden olan regresyon analizinin uygulanabilmesi için; bağımlı değişkenin normal dağılım göstermesi, bağımsız değişkenlerin normal dağılım gösteren toplum ya da toplumlardan çekilmiş olması ve hata varyansının normal dağılım göstermesi gereklidir. Genelde bağımlı değişken ölçülebilir nitelikte, sürekli bir değişken şeklindedir. Ancak her zaman bağımlı değişkeni ölçülebilir nitelikte elde etmek mümkün olmayabilir. Bu ve benzeri varsayımların karşılanamadığı durumlarda basit ya da çoklu regresyon analizleri uygulanamamaktadır (Özdamar, 2002; Çokluk, 2010). Özellikle sosyal bilim ve sosyo-ekonomik araştırmalarda, regresyon analizinin gerektirdiği varsayımların sağlanamadığı veri yapılarında, değişkenler arasındaki ilişkinin açıklanmasında ve bağımlı değişkenin alacağı sınıflama değerinin tahminlenmesinde Lojistik Regresyon analizinden sıklıkla yararlandığı görülmektedir.

Lojistik regresyon analizinin kullanım amacı, en az değişken kullanarak en iyi uyuma sahip olacak şekilde bağımlı değişken ile bağımsız değişkenler kümesi arasındaki ilişkiyi tanımlayabilen ve genel olarak kabul edilebilir bir model kurmak (Aktaş ve Erkuş, 2009; Burmaoğlu, Oktay ve Üstün, 2009; Fabowale, Orser ve Riding, 1994); bu model yardımıyla bireylerin hangi sınıfın üyesi olduğunu kestirmede bir regresyon denklemi oluşturarak iki veya daha fazla gruba ilişkin sınıflama tahmini yapmaktır. Kurulan lojistik regresyon modeli yardımıyla gözlemleri, verilerin yapısında bulunan olası gruplara atamak ta mümkün olabilmektedir (Özdamar, 2002). Esasen kümeleme analizi ve diskriminant analizi de bu amaçla kullanılmaktadır. Ancak hem veri yapılarındaki bazı kısıtlardan, hem de normal dağılım ve ortak varyanskovaryans matrisine sahip olma koşullarının sağlanamamasından dolayı diskriminant ve kümeleme analizinin uygulanması mümkün olamamaktadır (Press ve Wilson, 1978).

Birden çok bağımsız değişkenin yer aldığı lojistik modeller, diğer çok değişkenli regresyon modellerine benzemekle birlikte bağımsı değişkenin türüne bağlı olarak katsayıların yorumlanması farklı ve kolaydır (Agresti, 2007; Özdamar, 2002; Press ve Wilson, 1978; Tatlidil, 2002). Regresyon analizleri ile bağımlı değişken ile bağımsız değişken ya da değişkenler arasındaki matematiksel bağıntı analiz edilerek bağıml değişkenin alabileceği değer tahmin edilirken; lojistik regresyon analizi ile bağımlı değişkenin alabileceği değerlerden birinin gerçekleşme olasilığ tahmin edilir (Bircan, 2004). Lojistik regresyonda tahminlenen değer bir olasılıktır, kısaca lojistik regresyon ile bağımlı değişkenin alabileceği değerlerden birinin gerçekleşme olasıllğı tahmin edilmektedir (Coşkun, Kartal, Coşkun ve Bircan, 2004).

Eğer bağımlı değişken iki şıklı bir kategorik değişken ise İkili (Binary) Lojistik Regresyon; eğer bağımlı değişken ikiden çok kategorili bir değişken ise İsimsel veya Çoklu (Multinominal) Lojistik Regresyon; son olarak bağımlı değişken sıralama ölçeğiyle (hafif, orta, ağır vb.) elde edilmiş ise Sıralı (Ordinal) Lojistik Regresyon Modeli uygulanır (Çokluk, 2010; Özdamar, 2002).

"Bağımlı değişken üzerinde açıklayıcı değişkenlerin etkileri olasılık olarak elde edilerek, risk faktörlerinin olasilıklı olarak belirlenmesi sağlanır" (Özdamar, 2002: 624). Lojistik regresyon analizi elde edilen denklemde P olayın gözlenme olasılığını gösterirken; incelenen bir olayın olasılığının kendi dışında kalan diğer olayların olasıllğına oranı Odds ile ifade edilir. (Çolak, 2002). Lojistik modeldeki etkiler Odds 'ye dayanır. Bu istatistik $\mathrm{X}=1$ olan bireylerin $\mathrm{X}=0$ olan bireylere nazaran bağımlı değişkeni kaç kat daha fazla 1 olarak görüleceği olasıllğını verir (Bircan, 2004). Lojistik regresyon denkleminde Odds oranı, Exp ( $\beta$ ) olarak ifade edilir (Girginer ve Cankuş, 2010).

Ayrıca, verileri lojistik regresyonla analiz ederken, R2'ye eşdeğer bir istatistik mevcut değildir. R2 terimi, modelin öngörülen değerleri ile gerçek değerler arasındaki korelasyonun karesidir. Bu korelasyon -1 'den 1 'e kadar değişebilir, ve R2 ise 0 'dan 1 'e kadar değişir. Tahmin edilen değerler ile gerçek değerler arasındaki korelasyonun büyüklügü ne kadar büyük olursa olsun, korelasyon pozitif veya negatiftir. Cox ve Snell, Nagelkerke ve Mc Fadden vb. R2 değerlerinin hepsi; modelin sonuç verisine daha iyi uyduğunu kabul eder. Sözde R2 değerleri bağımsız olarak yorumlanamaz veya veri kümeleriyle karşılaştırılamazken, aynı veri kümesinde aynı sonucu tahmin eden çoklu modelleri değerlendirmede daha geçerli ve yararlıdır. Başka bir deyişle, bağlamsız bir R2 istatistiğinin çok az anlamı bulunmakta olup, daha yüksek R2 değeri hangi modelin sonucu daha iyi tahmin ettiğini gösterir. Bunlar genellikle modelin uygunluk ölçüsü olarak kullanilır (Long ve Freese, 2006). 
Bu çalışmada, kategorik ("Tasarruflu tüketim", "Geri dönüşüme destek", ve "Çevreci satın alma" davranışları) olarak üç seçenekli oluşturulan bağımlı değişkene; sayısal olarak ölçülen "evrenselcilik", "iyilikseverlik", "başarı", "güç" ve "hazcıllk" değer yapıları olarak belirlenen bağımsız değişkenler ile yaş ve cinsiyet bağımsız değişkenlerinin etkilerinin anlaşılması amacıyla İsimsel/Çoklu Lojistik Regresyon analizi uygulanmış ve kurulan bir model yardımıyla anlaşılmaya çalışılmışırı.

Bağımlı değişkenin sınıflandırılabilmesi amacıyla; katılımcıların çevresel tutumları, Dunlap ve Van Liere (1978) tarafindan geliştirilen Yeni Ekolojik Paradigma Ölçeğindeki maddelerin "Tasarruflu tüketim", "Geri dönüşüme destek", ve "Çevreci satın alma" davranışı şeklinde olmak üzere üç (3) kategoriye ayrılmıştır. Katılımcıların baskın çevreci davranış tipinin sınıflandırılması için her grup skorlarının aritmetik ortalaması dikkate alınmış, en yüksek ortalama skor kişinin çevreci davranışının belirlenmesinde belirleyici olmuştur. Çevreci davranış tipi olarak iki veya üç sınıf ortalama skoru eşit olan bireyler baskın çevreci davranışı belirgin olmadığı gerekçesiyle analiz dışına alınarak verileri değerlendirilmemiştir. Schwartz'ın Değer Kuramındaki değer ölçeğinde(SVS) 24 madde kapsamında ölçülen "evrenselcilik", "iyilikseverlik", "başarı", "güç̧" ve "hazclık" değer yapılarının skor toplamları ile yaş ve cinsiyet değişkenleri bağımsız değişkenler olarak modele olan etkileri incelenmek üzere analize alınmıştır. Kurulan İsimsel Lojistik Modelin değissken yapıları aşağıdaki gibidir.

Çevreci davranış tipi ile ilgili kurulacak isimsel lojistik regresyon modelindeki bağımlı değişken Y; 0Tasarruflu tüketim, 1-Geri dönüşüm desteği ve 2-Çevreci satın alma; şeklinde kodlanmıştır. Çevreci davranış eğilimi üzerinde etkisi olduğu düşünülen bağımsız değişkenler ise; X2: Cinsiyet (1=Kadın, 2=Erkek) şeklinde kategorik değişken; X1: Yaş (katıllımcıların bilgilerinde kategorik olarak sınıflandırılmıstır), X3: Evrenselcilik, X4: İyilikseverlik, X5: Güç, X6: Başarı ve X7: Hazcılık şeklinde sayısal değişken olarak modele alınmıştır.

Daha önce de belirtildiği gibi, lojistik regresyon bağımsız değişkenlerin dağılımlarıla ilgili herhangi bir varsayım gerektirmemesine rağmen lojistik regresyonun kullanımı ile ilgili önemli bazı noktalar da bulunmaktadır, bunlar aşağıdaki gibi sıralanabilir (Çokluk, 2010):

Bağımsız değiskkenler arasinda çoklu bağlantı olmamasi: Tablo 2'de verilerin korelasyonlarının 0,70 'den büyük olmaması nedeniyle bağımsız değişkenler arasında çoklu bağlantı (multicollinearity) sorunu olmadığı görülmüştür.

Tablo 2. Degerler Korelasyon Matrisi

\begin{tabular}{|l|c|c|c|c|c|}
\hline & EVrenselcilik & İyilikseverlik & Güç & Başart & Hazc1lk \\
\hline Evrenselcilik & 1 & 0,260 & 0,171 & 0,301 & 0,283 \\
\hline İyilikseverlik & 0,260 & 1 & 0,140 & 0,406 & 0,108 \\
\hline Güç & 0,171 & 0,140 & 1 & 0,321 & 0,473 \\
\hline Başarı & 0,301 & 0,406 & 0,321 & 1 & 0,459 \\
\hline Hazcılık & 0,283 & 0,108 & 0,473 & 0,459 & 1 \\
\hline
\end{tabular}

Aşır (uc) değerler olmamasi: İsimsel Lojistik Regresyon analizi sırasında outliers olarak hesaplanan sınır \%99 güven ve 5 bağımsız değişken olmak üzere Chi-square değeri 15,09 dur. Hesaplanan Mahalanobis D2 değerine göre hesaplanan standardize değerler kapsamında +3.0 'den büyük -3.0 ' den küçük değere sahip veriler elenerek toplamda 203 anket verisi analize alınmıştır.

Ömeklem sayısımın yeterli olması: Bağımlı değişkenin ikiden fazla sınıfinın olması durumunda, geçerli bir hipotez testi yapılabilmesi için, her bağımsız değişkende en az 50 kişilik bir veri büyüklüğüne ihtiyaç vardır. Bu sayının bazı kaynaklarda her bağımsız değişken için minimum 20 olması gerektiği vurgulanmaktadır (Çokluk, 2010). Örneklemde tahmin edilen değerlerin güvenilirliğinin azalmaması için modelde ele alınacak bağımsız değişken sayısının en az 20 katı kadar veri olması gerekliliği $(5 * 20=100<203$ olmak üzere) sağlanmıştır.

\section{Bulgular}

\section{Katılımc1 Bulguları}

Araştırma katılımcılarının yaş, cinsiyet, okul durumu gibi bazı gruplayıcı sorular kapsamındaki elde edilen bulguları şunlardır: Katılımcıların \%54,2 ‘si kadın, \%45,8 'i erkektir. \%36,8 ’i 17-19 yaş, \%38,4 ’ü 2022 yaş aralığında ve $\% 24,8$ 'i ise 23 yaş ve üzerindedir. Yine katılımcıların \%88,3 'ü farklı okullarda okuyan lisans öğrencileri ve $\% 11,7$ 'si ise önlisans ve yüksek lisans öğrencileridir. 


\section{Tanımlayıc1 Bulgular}

Sürdürülebilir çevre davranışı/çevreye duyarlı tüketim davranışı tiplerinin ayrıştırılması amacıyla; katılımcı cevapları skorlarının Yeni Ekolojik Paradigma Ölçeğindeki maddelere, Tasarruflu tüketim, Geri dönüşüme destek ve Çevreci satın alma davranışı tutumuna yönelik belirlenen frekans dağılımları ve yüzdeleri Tablo 3 'te verilmiștir.

Tablo 3. Katılımalarm Cevreci Davramıs Karakteristikleri

\begin{tabular}{lccc}
\hline & Çevreci Davranıs Karakteristikleri & Sayı & $\%$ \\
\hline Tasarruflu tüketim & 103 & 50,7 \\
Geri dönüşüme destek & 78 & 38,4 \\
Çevreci satınalma & 22 & 10,8 \\
\hline Toplam & 203 & 100,0 \\
\hline
\end{tabular}

\section{İsimsel Lojistik Regresyon Analiz Bulguları}

İsimsel Lojistik Regresyon analizinde ileri doğru adımsal olabilirlik oranı (likelihood ratio) ve "main effects" modeli seçilmiştir. Bu yöntem ile elde edilen lojistik regresyon modelin uyum bilgisi ve uyum iyiliği sonuçları Tablo 4 'te gösterilmiştir.

Tablo 4. Modelin Uyum Bilgisi (Goodness of fit) ve Uyum Iyiliği

\begin{tabular}{lcccc}
\hline & -2 Log Likelihood & Ki-Kare & df & $P$ \\
\hline Sabit & 384,022 & - & - & - \\
Model & 343,097 & 40,925 & 14 & 0,0001 \\
Pearson & - & 366,713 & 186 & 0,082 \\
Sapma & - & 343,097 & 186 & 0,089 \\
\hline
\end{tabular}

Tablo 4 incelendiğinde, model uyum bilgisi $\left(\chi^{2}=40,925 ; \mathrm{sd} .=14 ; \mathrm{p}=0,0001\right)$ ile model uyum iyiliğinde pearson $\left(\chi^{2}=366,713\right.$; sd. $\left.=186 ; \mathrm{p}=0,082\right)$ ve sapma $\left(\chi^{2}=3453,097\right.$; sd. $\left.=186 ; \mathrm{p}=0,089\right)$ değerlerine bakıldığında; P değerleri $(0,082$ ve 0,089$)>0,05$ olduğundan, lojistik regresyon modelin genel olarak anlamlı olduğu söylenebilir.

Pseudo R2 değerleri, modelin öngörülen değerleri ile gerçek değerler arasındaki korelasyonun karesidir ve model tarafından açıklanan varyasyon oranını göstermektedir (Chan, 2005). SPSS 20,0 uygulamasıyla elde edilen, Cox ve Snell $(0,184)$, Nagelkerke $(0,216)$ ve McFadden $(0,207)$ değerleri aynı zamanda modelin uyumunun testi amacıyla da kullanılmaktadır. Mc Fadden tarafindan Pseudo R2 değeri 0,2-0,4 değerleri arasında bir değere sahip olan modelin, model uyumlarının oldukça iyi olduğu ifade edilmektedir (Domencich ve McFadden, 1975). Araştırma modelinde Mc Fadden değeri $(0,0207>0,2)$ olduğu görüldüğünden model uyumunun iyi olduğu söylenebilir.

Lojistik regresyon modelinde yer alan bir bağımsız değişkenin anlamlılığını ölçmek için olabilirlik oran testinden yararlanılır. Araştırma modelinde kullanılan bağımsız değişkenlerin bağımlı değişkeni bir bütün olarak anlamlı bir şekilde açıklayıp açıklamadığının incelendiği Olabilirlik Oran testleri (Likelihood Ratio Tests) Tablo 5 'te gösterilmiştir.

Tablo 5. Olabilirlik Oran Testi Sonuçlar

\begin{tabular}{|c|c|c|c|c|}
\hline Etki & $\begin{array}{l}-2 \text { Log Likelihood of Reduced } \\
\text { Model }\end{array}$ & Ki-Kare & $d f$ & $P$ \\
\hline Sabit & $343,097 \mathrm{a}$ & 0,000 & 0 & . \\
\hline Yaş & 350,443 & 7,346 & 2 & $0,025 *$ \\
\hline Cinsiyet & 348,056 & 4,959 & 2 & 0,084 \\
\hline Evrenselcilik & 358,162 & 15,064 & 2 & $0,001 *$ \\
\hline İyilikseverlik & 353,949 & 10,852 & 2 & $0,004 *$ \\
\hline Güç & 344,394 & 1,297 & 2 & 0,523 \\
\hline Başarı & 348,906 & 5,809 & 2 & $0,045 *$ \\
\hline Hazcilık & 346,445 & 3,348 & 2 & 0,188 \\
\hline
\end{tabular}


Tablo 5 'teki sonuçlar incelendiğinde bağımlı değişken olarak belirlenen Çevreci davranış tipi üzerinde bağımsız değişkenlerden Yaş, Evrenselcilik, İyilikseverlik ve Başarı bağımsız değişkenlerinin \% 05 ve daha az hata payında anlamlı oldukları; Cinsiyet, Güç ve Hazcılık bağımsız değişkenlerinin ise anlamlı olmadıkları belirlenmiştir.

Bağımlı değişken olarak alınan çevreci davranış tipi ile ilgili kurulan isimsel lojistik regresyon modelinin sonuçları Tablo 6 'da verilmiştir. Modelde, çevreci satınalma eğilimi referans kategorisi olarak alınmıştır.

Tablo 6. Cevreci Davranış Tipine Yönelik İsimsel Lojistik Regresyon Analizi Sonuçları

\begin{tabular}{|c|c|c|c|c|c|c|}
\hline Değiskenler / Sinıf & $\beta$ & S.E. & Wald & $d f$ & Sig. & $\operatorname{Exp}(\beta)$ \\
\hline \multicolumn{7}{|c|}{ Tasartuflu tüketim eğilimi } \\
\hline Sabit & 11,997 & 3,748 & 10,243 & 1 & 0,001 & \\
\hline Yaş & $-0,191$ & 0,076 & 6,263 & 1 & $0,012 *$ & 0,826 \\
\hline [Cinsiyet $=$ Kadin] & 0,385 & 0,521 & 0,546 & 1 & 0,460 & 1,469 \\
\hline [Cinsiyet=Erkek] & $0^{\mathrm{b}}$ & 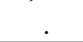 & & 0 & & . \\
\hline Evrenselcilik & $-0,312$ & 0,106 & 8,628 & 1 & 0,003* & 0,732 \\
\hline İyilikseverlik & 0,310 & 0,115 & 7,292 & 1 & $0,007 *$ & 1,363 \\
\hline Güç & 0,106 & 0,098 & 1,181 & 1 & 0,277 & 1,112 \\
\hline Başarı & $-0,410$ & 0,190 & 4,687 & 1 & $0,030 *$ & 0,663 \\
\hline Hazcilik & 0,287 & 0,156 & 3,371 & 1 & 0,066 & 1,333 \\
\hline \multicolumn{7}{|c|}{ Geri dönüşüm desteği } \\
\hline Sabit & 8,882 & 3,683 & 5,817 & 1 & 0,016 & \\
\hline Yaş & $-0,185$ & 0,075 & 6,092 & 1 & $0,014 *$ & 0,831 \\
\hline [Cinsiyet=Kadin] & 0,959 & 0,522 & 3,377 & 1 & $0,046^{*}$ & 2,609 \\
\hline [Cinsiyet=Erkek] & $0^{\mathrm{b}}$ & . & , & 0 & & . \\
\hline Evrenselcilik & $-0,180$ & 0,107 & 2,814 & 1 & 0,093 & 0,835 \\
\hline İyilikseverlik & 0,117 & 0,107 & 1,187 & 1 & 0,276 & 1,124 \\
\hline Güç & 0,099 & 0,097 & 1,041 & 1 & 0,308 & 1,104 \\
\hline Başarı & $-0,246$ & 0,188 & 1,707 & 1 & 0,191 & 0,782 \\
\hline Hazcılık & 0,240 & 0,156 & 2,359 & 1 & 0,125 & 1,272 \\
\hline
\end{tabular}

*: \%5 anlamlık seviyesinde anlamlıdır. **: Referans kategorisi: Çevreci satınalma eğilimi

Tablo 6'daki analiz sonuçlarına göre; referans kategorisi olan çevreci satınalma eğilimi gösteren bireylere göre, Tasarruflu tüketim eğilimli bireylerin; Evrenselcilik $(\mathrm{p}=0,003)$, iyilikseverlik $(\mathrm{p}=0,007)$ ve başarı $(\mathrm{p}=0,030)$ değerleri açısından ve gruplayıcı değişken olan yaş değişkeni $(\mathrm{p}=0,012)$ açısından $\% 5$ hata payında anlamlı düzeyde farklı davranış gösterdikleri belirlenmiştir.

$\operatorname{Odds}(\operatorname{Exp}(\beta))$ oranına göre Evrenselcilik değerinin, \%1 birim artması durumunda Tasarruflu tüketim eğiliminde olan katılımcıların Çevreci satın alma eğilimindeki bireylere göre 0,732 kat $(\operatorname{Exp}(\beta)=0,732)$ daha az bir etkiye $(\beta=-0,312)$ sahip olma ihtimali olduğu söylenebilir. Buna göre; Evrenselcilik değerinin tasarruflu tüketim eğilimli bireylerdeki etkisinin çevreci satın alma eğilimdeki bireylere göre negatif olduğu anlaşılmıştır.

İylikseverlik değerinin tasarruflu tüketim eğiliminde olan katılımcılar açısından; çevreci satın alma eğilimindeki bireylere göre, 1,363 kat $(\operatorname{Exp}(\beta)=1,363)$ daha fazla olumlu bir etkiye $(\beta=0,310)$ sahip olduğu belirlenmiştir. İyilikseverlik değerinin tasarruflu tüketim eğilimli bireylerdeki etkisinin çevreci satın alma eğilimdeki bireylere göre çevreci davranışlarının şekillenmesinde pozitif bir etkiye sahip olduğu söylenebilir.

Başarı değeri açısından ise; tasarruflu tüketim eğilimindeki katılımcıların; çevreci satın alma eğilimindeki bireylere göre, 0,663 kat $(\operatorname{Exp}(\beta)=0,663)$ daha az bir etkiye $(\beta=-0,410)$ sahip olduğu belirlenmiştir. Başarı değerinin tasarruflu tüketim eğilimindeki bireylere etkisinin çevreci satın alma eğilimdeki bireylere göre olumsuz olduğu söylenebilir.

Gruplayıcı değişkenlerden olan cinsiyet değişkeni modelde anlamlı bir etkiye sahip değil iken yaş değişkeninin anlamlı bir etkisi olduğu gözlemlenmiştir. Buna göre; bireylerin \%1 yaşlarının artması durumunda tasarruflu tüketim eğilimi gösterme ihtimalinin çevreci satın alma eğilimli bireylere göre 0,826 kat $(\operatorname{Exp}(\beta)=0,826)$ daha az $(\beta=-0,191)$ olacağ1 tahmin edilmektedir. 
Yine Tablo 6 'daki analiz sonuçlarına göre; referans kategorisi çevreci satınalma eğilimi gösteren bireylere göre, Geri dönüşüme destek eğilimli bireylerin; Schwartz 'ın değer maddeleri açısından anlamlı bir farklı davranış göstermedikleri; gruplayıcı değişken olan yaş değişkeni $(\mathrm{p}=0,014)$ ve cinsiyet değişkeni $(0,046)$ açısından $\% 5$ hata payında anlamlı düzeyde farklı davranış gösterdikleri belirlenmiştir.

Buna göre; bireylerin yaşlarının \%1 artması durumunda tasarruflu tüketim eğilimi gösterme ihtimalinin çevreci satın alma eğilimindeki bireylere göre 0,831 kat $(\operatorname{Exp}(\beta)=0,831)$ daha az olacağı $(\beta=$ $0,185)$ belirlenmiştir. Ayrıca, kadınların erkeklere göre 2,609 kat $(\operatorname{Exp}(\beta)=2,609)$ daha fazla $(\beta=0,959)$ tasarruflu tüketim eğilimi gösterme ihtimali olduğu söylenebilir.

Kurulan isimsel modelin sınıflandırma başarısının anlaşılması için elde edilen sınıflandırma tablosu, Tablo 7 'de verilmiștir.

Tablo 7. Simflandirma Tablosu (\%)

\begin{tabular}{|l|c|c|c|c|}
\hline \multirow{2}{*}{\multicolumn{1}{|c|}{ Gözlenen }} & \multicolumn{4}{|c|}{ Tahminlenen } \\
\cline { 2 - 5 } & $\begin{array}{c}\text { Tasartuflu } \\
\text { Tüketim }\end{array}$ & Geri dönüsüme destek & $\begin{array}{c}\text { Cevreci } \\
\text { Satunalma }\end{array}$ & Doğru \\
\hline Tasarruflu tüketim & 76 & 21 & 4 & 75,2 \\
Geri dönüşüme destek & 40 & 36 & 2 & 46,2 \\
Çevreci satınalma & 6 & 12 & 4 & 18,2 \\
\hline Genel & 60,7 & 34,3 & 5,0 & 57,7 \\
\hline
\end{tabular}

Sınıflandırmanın doğruluğunun test edilmesi amaciyla oransal șans kriteri ve maksimum şans kriterinin hesaplanarak karşılaştırılması gerekmektedir (Burmaoğlu vd., 2009). Çevreci tüketim davranış eğilimlerini doğru tahmin edebilmek için sınıflama oranı \%25 oranında Oransal Şans Kriterinden (PCC) yüksek olmalıdır (Hair, Black, Babin, Anderson ve Tatham, 1998). Çevreci tüketim davranışları belirlenen katılımcı grupların öncelikli olasılık değerlerine ait veriler Tablo 3 'te verilmiştir. Grup içi öncelikli olasılık değerleri Oransal Şans Kriteri (Proportional Chance Criterion-PCC); 0,5072 + 0,3842 + 0,1082 = 0,416 $(\% 41,6)$ olarak bulunur. İsimsel lojistik regresyon analizi yardımıyla çevreci tüketim eğilimlerine göre sınıflandırılacak katılımcıların değer yapılarına göre sınıflandırılmaları ile ilgili doğru tahmin oranı Tablo 7 'de görüldüğü gibi \%57,7 bulunmuştur. Bu sinıflandırma yüzdesi yukarıda bulunan oransal şans kriterinden $(\% 41,6 * 1,25<\% 57,7)$ yüksek olduğu için sinıflandırmanın yeterli olduğu kabul edilir.

Bunun yanında toplam örneklem büyüklüğü ve grup sayısı ile doğru sınıflandırmaların sayısını karşılaştırmak için Press's Q değeri de kullanılmaktadır (Hair vd., 1998). Press's Q=[N- (nK)]2 / N(k-1) olmak üzere; $\mathrm{N}($ Örneklem büyüklüğ̈̈) $=203, \quad \mathrm{~K}(\mathrm{Grup}$ sayıs1) $=3, \quad \mathrm{n}$ (Doğru sinıflandırma sayıs $)=(0,577 * 203=117)$ olmak üzere Press's $Q=53,95$ tir. Bulunan Press's $Q$ değeri Ki-kare dağılımı kullanılarak belirlenen (\%5 anlamlılık düzeyinde) kritik değerle karşılaştırılır. Press's Q=53,95 > 5,99 (Kikare değeri, 0,95, 2 sd.) olduğundan; sınıflandırmanın şans kriterinden daha yüksek bir istatistiksel öneme sahip olduğu söylenebilir.

Tablo 7 'ye göre elde edilen modelin genel anlamda doğru sınıflandırma yüzdesinin \%57,7 olduğu bulunmuştur. Tasarruflu tüketim ve Geri dönüşüm desteği sinıfları açısından yeterli sayılabilecek bir sınıflandırma yüzdeleri elde edilirken; modelin uyum iyiliği yeterli olmasına rağmen Çevreci satınalma eğilimli bireyler için bulunan sınıflandırma yüzdesi düşük çıktığı için, modelin bu sınıf üyelerini tanımlamada yetersiz olduğu düşünülmektedir. Ancak bu durumun, bu sınıftaki birey sayısının az olmasından kaynaklandığı düşünülmektedir.

\section{Sonuç}

Araştırmanın amacı doğrultusunda isimsel lojistik regresyon analizi ile elde edilen bir model yardımıyla; değer tutumu bilinen genç bir kişinin ne şekilde çevreye duyarlı bir tüketim davranışı göstereceğinin tahmin edilmesi veya çevreci davranış eğilimleri bilinen genç bireylerin hangi değer yapılarında ayrışacağının kestirilmesi mümkün olabilir.

Elde edilen lojistik modelde, Tasarruflu tüketim eğilimi olan bireylerin Çevreci satınalma eğilimli bireylere göre "Kendini aşma" değer öbeğindeki "Evrenselcilik" boyutu açısından negatif bir ayrışmanın olduğu belirlenmiştir. Buna göre, bireylerin eşitlik, toplumsal adalet, çevreyi koruma, açık fikirlilik, barışçı bir dünya isteği, erdemli olma değerleri açısından negatif bir şekilde ayrıştıkları; araştırmada verileri dikkate alınan genç bireylerin Tasarruflu tüketim eğilimli olmalarındaki Evrenselcilik boyutunun etkisinin Çevreci satınalma eğilimli bireylere göre olumsuz olduğu belirlenmiştir. Kısaca, evrenselcilik değer anlayışları güçlü 
olan bireylerin tasarruflu tüketim eğilimli olma ihtimallerinin çevreci satın alma eğilimli olmaya göre negatif etkisi olduğu ifade edilebilir. Sonuç olarak, tasarruflu tüketim eğilimindeki bireylerin evrenselci değerlerinin çevreci satınalma eğilimli bireylere göre daha düşük olduğu anlaşılmaktadır.

Modelde, tasarruflu tüketim eğilimli bireylerin çevreci satınalma eğilimli bireylere göre "iyilikseverlik" boyutu açısından pozitif olarak ayrıştıkları belirlenmiştir. Genç bireylerin, dürüstlük, sadakat, yardımseverlik, sorumluluk sahibi olma ve bağışlayıcı olma değerleri açısından güçlü olma durumlarının tasarruflu tüketim eğilimini, çevreci satınalma eğilimine göre daha fazla olumlu yönde etkilediği anlaşılmaktadır. Kısaca, iyilikseverlik değer boyutunun bireylerin tasarruflu tüketim eğilimli olmalarına yaptığı katkının çevreci satın alma eğilimli olmaya yaptığı katkıdan fazla olduğu ifade edilebilir. Yani, iyilikseverlik değer boyutunun, tasarruflu tüketim eğilimi göstermede çevreci satınalmaya göre daha etkili olduğu sonucu çıarılabilir.

Lojistik modelde anlamlı çıan diğer bir değişken olan "Kendini geliştirme" değer öbeğindeki başarı değeri açısından; Tasarruflu tüketim eğilimli bireylerin çevreci satın alma eğilimli bireylere göre negatif ayrıştıkları belirlenmiştir. Buna göre, tasarruflu tüketim eğilimli bireylerin, Çevreci satın alma eğilimindeki bireylere göre; başarılı olma, hırslı olma, sözü geçen birisi olma ve yetkinlik değerlerinde daha düşük değer yapılarına sahip oldukları görülmüştür. Kısaca, başarıya daha fazla odaklanan bireylerin, tasarruflu tüketim eğilimi göstermeye olan eğilimlerinin çevreci eğilimli bireylere göre daha negatif olduğu söylenebilir. Buna göre, başarı değer yapısı güçlü olan bireylerin daha az tasarruflu tüketim eğilimi gösterecekleri anlaşılabilir.

Gruplayıcı değişkenlerden yaş değişkenine bakıldığı zaman, tasarruflu tüketim eğilimli genç bireylerin yaşlarının artmasının tasarruflu tüketim eğilimi göstermeye olan eğilimlerine çevreci bireylere göre daha az etkisi olacağı; kısaca yaşın çevreci satın alma eğilimli bireylere göre etkisinin daha olumsuz olduğu tahmin edilmektedir.

Geri dönüşüme destek eğilimli bireylerin Çevreci satınalma eğilimli bireylere göre karşılaştırmalarının yapıldığı sonuçlar incelendiğinde, değer yapıları açısından ayrışacak farklar elde edilemezken; yaş ve cinsiyet gruplayıcı değişkenleri açısından anlamlı farklar elde edilmiştir. Buna göre, yaş değişkeni açısından bakıldığı zaman, Geri dönüşüme destek eğilimli genç bireylerin yaşları arttıkça Geri dönüşüme destek eğilimi göstermeye olan eğilimlerinin çevreci bireylere göre daha az olduğu belirlenmiştir. Cinsiyet değişkeni açısından ise geri dönüşüm desteği eğilimi olan kadınların erkeklere göre eğilimlerinin çevreci satınalma eğimindeki kadınlara göre daha fazla olduğu görülmüştür. Buna göre geri dönüşüm desteği eğilimi göstermede cinsiyetin etkisi çevreci satın alma eğilimi göstermeye göre daha yüksektir.

\section{Tartışma ve Öneriler}

Çalışma bulguları, Stern vd. 'nin (1999) yaptığı çalışma ile kısmen; Stern vd. (1998), Stern ve Dietz (1994), Karp (1996), Thøgersen ve Ölander (2002), Nordlund ve Garvill (2002) tarafindan yapilan çalışmalarla da genel çevreci davranış ile değer ilişkisinin bulunmuş olmasından dolayı genel anlamda örtüşürmekte iken; kendini aşma ve kendini geliştirme öbeklerindeki farklı değerler için olumlu/olumsuz sonuçların elde edilmesi açısından ise Nordlund ve Garvill (2003), Poortinga vd. (2004) ve Karalar ve Kiracı (2010) 'nın çalışmalarındaki tasarruflu tüketim davranışı eğiliminin kendini aşma boyutu ile ilişkisinin olumlu bulunmuş olmasından örtüşmemektedir.

Schwartz'ın değerler modelinin evrensel olarak geçerli olup olmadığı birçok çalısmanın konusunu oluştururken (Schwartz ve Bardi, 2001; Schwartz ve Sagie, 2000); Schwartz'n Modelindeki Değerlerin tüm kültürlerde var olduğu, farklı kültürlerde farklı değer önceliklerinin olabileceği de unutulmamalıdır. Değerlerin ülkeden ülkeye değişkenlik göstermesi beklenen bir durumdur, bu farklılıkların kaynağı kültürel değişkenlikler de olabilir (Demirutku ve Sümer, 2010).

Bu çalışmada, sürdürülebilir çevre davranışı veya çevreci tüketim davranış eğiliminin bütünü yerine; Tasarruflu tüketim, Geri dönüşüme destek verme ve Çevreci satın alma davranış eğilimlerine yönelik olarak Schwartz'nn değerler modelindeki sosyal ve bireysel değerler ayrımındaki bireysel değer yapıları ile ilişkilerin anlaşılması amaçlanmıştır. Çalışmanın bu yönüyle literatüre farklı ve önemli bir katkı sağlayacağı düşünülmektedir.

Çalışma kapsamında ABD Bozeman şehrinde yaşayan üniversite öğrencilerinin Çevreye duyarlı tüketim davranışlarının kendi içinde Tasarruflu tüketim, Geri dönüşüme destek verme ve Çevreci satın alma eğilimlerine yönelik sınıfsal farklılıkları Schwartz, (1992), değerler modelindeki Kendini aşma ve Kendini gerçekleştirme değer öbekleri içindeki değer yapılarına göre sınıflandırılmasına çalışılmışıır. 
Bulgular, tasarruflu tüketim eğilimli bireylerde, çevreci satınalma eğilimli bireylere göre; evrenselcilik ve başarı değerlerinin negatif yönlü; iyilikseverlik değerinin ise pozitif ayrıştığını göstermiştir. Elde edilen sonuçların daha geniş alanlarda ve daha çok sayıdaki örneklem üzerinde tekrarlanması, özellikle Türkiye'de ve başka ülkelerdeki farklı kültürlerle de karşılaştırılmalı olarak yapılması ile çevresel davranışların altındaki değer yapılarının anlaşılması daha mümkün hale gelebilecektir.

Bir toplumda yaşayan tüm bireylerin o toplumun toplumsal değerlerini aynı düzeyde önemsemeleri mümkün değildir. Sürekli değişen dünyada değerler de değişmektedir. Zaman içinde geçen olaylar, alınan eğitimler bireylerde farklı bakış açılarına yol açarken; bu farklılıklar değerler üzerinde de etkili olmaktadır. Bu durum, değerlerin farklı niteliğe sahip insanlara göre değiştiğini göstermektedir. Ancak, genç bireylerin çevreci davranış eğilimlerinde hangi değer yapılarının baskın olduğunun anlaşılabilmesiyle, çocukluktan itibaren bu değer yapılarının çocuklara kazandırılarak sürdürülebilir çevre davranışlarının yönetilmesi ve kontrol edilebilmesinin olası olduğu düşünülmektedir.

Dünyanın herhangi bir yerindeki yaşanan çevresel bir olay artık tüm dünya toplumlarını ilgilendirmektedir. İnternet ve bilgi teknolojileriyle, ulaşım araçlarının hızı ve çeşitliliği ile küçülen dünyada kültürlerin etkileşmesi, değerlerin transfer edilmesi ve paylaşılması son derece kolay hale gelmiştir. Özellikle tüm dünya toplumlarının sürdürülebilir çevresel davranışlarının geliştirilebilmesinde ve tutundurulmasında değer yapılarının anlaşılması büyük önem arz etmektedir.

Bu çalıșma da anket yapılan kişi sayısının az olması ve örneklemin belirlenmesinde olasılıksız bir örnekleme yöntemi kullanılması araştırmanın en önemli sınırllıklarından olup sonuçların genellenmesini engellemektedir. Bu açıdan Yazarlar bu konudaki çalışmalarını öncelikle Türkiye'de ve daha sonra da başka kültür yapıları üzerinde sürdürmeyi planlamaktadırlar.

\section{Etik Beyan}

“Schwarzt'ın Sosyal Değerler Modelindeki Bireysel Değerlere Göre Tüketicilerin Çevreye Duyarlı Tüketim Davranışlarının İsimsel Lojistik Regresyon Analizi İle İncelenmesi” başlıklı çalışmanın yazım sürecinde bilimsel, etik ve alıntı kurallarına uyulmuş; toplanan veriler üzerinde herhangi bir tahrifat yapılmamıs ve bu çalışma herhangi başka bir akademik yayın ortamına değerlendirme için gönderilmemiştir.

\section{Kaynakça}

Agresti, A., (2007). An introduction to ccategorical data analysis. Hoboken, NJ: Wiley.

Aktaş, C. ve Erkuş, O. (2009). Lojistik Regresyon analizi ile Eskişehir'in Sis kestiriminin incelenmesi. İstanbul Ticaret Üniversitesi Fen Bilimleri Dergisi, 8(16), 47-59.

Bagozzi, R. P. ve Dabholkar, P. A. (1994). Consumer recycling goals and their effect on decisions to recycle: A means-end chain analysis. Psychology \& Marketing, 11(4), 313-340.

Bircan, H. (2004). Lojistik regresyon analizi: Tip verileri üzerine bir uygulama. Kocaeli Üniversitesi Sosyal Bilimler Enstitüsü Dergisi, 2, 185-208.

Burmaoğlu, S., Oktay, E. ve Üstün, Ö. (2009). Birleşmiş milletler kalkınma programı beşeri kalkınma endeksi verilerini kullanarak diskriminant analizi ve lojistik regresyon analizinin sinıflandırma performanslarının karşılaştırılması. Savunma Bilimleri Dergisi, 8(2), 23-49.

Chan, Y. H. (2005). Biostatistics 305. Multinomial logistic regression. Singapore Medical Journal, 46(6), 259.

Corraliza, J. A. ve Berenguer, J. (2000). Environmental values, beliefs, and actions: A situational approach. Environment and Behavior, 32(6), 832-848.

Coşkun, S., Kartal, M., Coşkun, A. ve Bircan, H. (2004). Lojistik regresyon analizinin incelenmesi ve diş hekimliğinde bir uygulamas1. Cumburiyet Üniversitesi Diş Hekimliği Fakültesi Dergisi, 7(1-2004). Geliş tarihi gönderen http:/ / eskidergi.cumhuriyet.edu.tr/makale/958.pdf

Çokluk, Ö. (2010). Lojistik regresyon analizi: Kavram ve uygulama. Kuram ve Uygulamada Eğitim Bilimleri, 10(3), $1357-$ 1407.

Çolak, E. (2002). Koşullu ve simırlandırlmış lojistik regresyon yöntemlerinin karş̧laştırlması ve bir uygulama (Yüksek Lisans Tezi). Osmangazi Üniversitesi, Eskişehir.

Demirutku, K. ve Sümer, N. (2010). Temel değerlerin ölçümü: Portre Değerler Anketi’nin Türkçe uyarlaması. Türk Psikoloji Yazlar, 13(25), 17-25.

Doğan, İ. (2002). Sosyoloji-kavramlar ve sorunlar (5. Bask1). Ankara: Pegema Yayınc1lık.

Domencich, T. A. ve McFadden, D. (1975). Urban travel demand-a behavioral analysis.

Dunlap, R. E., Grieneeks, J. K. ve Rokeach, M. (1983). Human values and pro-environmental behavior, 145-168.

Dunlap, R. E. ve Van Liere, K. D. (1978). The "new environmental paradigm". The Journal of Environmental Education, 9(4), 10-19.

Evans, M., Jamal, A. ve Foxall, G. (2006). Consumer behaviour. John Wiley and Sons Ltd. 
Fabowale, L., Orser, B. ve Riding, A. (1994). Gender, structural factors, and credit terms between Canadian small businesses and financial institutions. Faculty of Business, Ryerson Polytechnic University. Geliş tarihi gönderen http://findarticles.com/p/articles/mi_hb6648/is_n4_v19/ai_n28670392/

Gardner, G. T. ve Stern, P. C. (2002). Environmental problems and human behavior. Boston, MA: Pearson Custom Publishing.

Girginer, N. ve Cankuş, B. (2010). Eskişehir'de belediye hizmetlerine ilişkin alg1 ve memnuniyetin ikili lojistik regresyon analizi ile ölçülmesi. Eskişehir Osmangaz̧i Üniversitesi Sosyal Bilimler Dergisi, 11(1), 297-322.

Grunert, S. C. ve Juhl, H. J. (1995). Values, environmental attitudes, and buying of organic foods. Journal of Economic Psychology, 16(1), 39-62.

Hair, J. F., Black, W. C., Babin, B. J., Anderson, R. E. ve Tatham, R. L. (1998). Multivariate data analysis (C. 5). Prentice hall Upper Saddle River, NJ.

Hofstede, G. (1991). Cultures and organizations: Culture of the mind. New York, NY: McGraw-Hill.

Kağıtçıbaşı, Ç. (1990). Insan aile kültür. İstanbul: Remzi Kitabevi.

Kapıkıran, N. A. ve Gündoğan, A. (2016). Çocukların değerlerinin ölçülmesi: Portrait değerler ölçeğinin Türkçe’ye uyarlanmas1. Ege Ë̆itim Dergisi, 17(2), 620-639.

Karalar, R. ve Kirac1, H. (2010). Bireysel değerlerin sürdürülebilir tüketim davranışı üzerindeki etkisini belirlemeye yönelik öğretmenler üzerinde bir araştırma. İsletme Araștırmalar Dergisi, 2(2), 79-106.

Karp, D. G. (1996). Values and their effect on pro-environmental behavior. Environment and Behavior, 28(1), 111-133.

Kluckhohn, C. (1951). Values and value-orientations in the theory of action: An exploration in definition and classification. Cambridge, MA: Harvard University Press.

Long, J. S. ve Freese, J. (2006). Regression models for categorical dependent variables using Stata. Stata Press.

McCarty, J. A. ve Shrum, L. J. (1994). The recycling of solid wastes: Personal values, value orientations, and attitudes about recycling as antecedents of recycling behavior. Journal of Business Research, 30(1), 53-62.

Nordlund, A. M. ve Garvill, J. (2002). Value structures behind proenvironmental behavior. Environment and Behavior, 34(6), 740-756.

Nordlund, A. M. ve Garvill, J. (2003). Effects of values, problem awareness, and personal norm on willingness to reduce personal car use. Journal of Environmental Psychology, 23(4), 339-347.

Özdamar, K. (2002). Paket programlar ile istatistiksel veri analizi (C. 1-2). Eskisehir: Kaan Kitabevi.

Özgür, E. (2013). Yaşa göre değer farklılıkları ve siyasi kuşak aidiyeti. Sosyoloji Dergisi, 3(26), 45-76.

Özkalp, E. (2005). Sosyolojizy giris (14. Bask1). Bursa.: Ekin Kitabevi Yayınları.

Poortinga, W., Steg, L. ve Vlek, C. (2004). Values, environmental concern, and environmental behavior: A study into household energy use. Environment and Behavior, 36(1), 70-93.

Press, S. J. ve Wilson, S. (1978). Choosing between logistic regression and discriminant analysis. Journal of the American Statistical Association, 73(364), 699-705.

Rokeach, M. (1973). The nature of human values. Free press.

Schultz, P. W., Gouveia, V. V., Cameron, L. D., Tankha, G., Schmuck, P. ve Franěk, M. (2005). Values and their relationship to environmental concern and conservation behavior. Journal of Cross-cultural Psychology, 36(4), 457475.

Schultz, P. W. ve Zelezny, L. (1999). Values as predictors of environmental attitudes: Evidence for consistency across 14 countries. Journal of Environmental Psychology, 19(3), 255-265.

Schwartz, S. H. (2009). Basic human values. Cross-National Comparison Seminar on the Quality and Comparability of Measures for Constructs in Comparative Research: Methods and Applications, Bolzano (Bozen), Italy, June 10-13, 2009.

Schwartz, S. H. ve Shalom, H. (1977). Normative influences on altruism. İçinde Advances in experimental social psychology (C. 10, ss. 221-279). Elsevier.

Schwartz, S. H. ve Shalom, H. (1992). Universals in the content and structure of values: Theoretical advances and empirical tests in 20 countries. Içinde Advances in experimental social psychology (C. 25, ss. 1-65). Elsevier.

Schwartz, S. H. ve Shalom, H. (1994). Beyond individualism/collectivism: New cultural dimensions of values. Sage Publications, Inc.

Schwartz, S. H., Shalom, H. ve Bardi, A. (2001). Value hierarchies across cultures: Taking a similarities perspective. Journal of Cross-cultural Psychology, 32(3), 268-290.

Schwartz, S. H., Shalom H. ve Bilsky, W. (1987). Toward a universal psychological structure of human values. Journal of Personality and Social Psychology, 53(3), 550.

Schwartz, S. H., Shalom H. ve Bilsky, W. (1990). Toward a theory of the universal content and structure of values: Extensions and cross-cultural replications. Journal of Personality and Social Psychology, 58(5), 878.

Schwartz, S. H., Shalom H. ve Sagie, G. (2000). Value consensus and importance: A cross-national study. Journal of Cross-cultural psychology, 31(4), 465-497.

Steg, L. ve Vlek, C. (2009). Encouraging pro-environmental behaviour: An integrative review and research agenda. Journal of Environmental Psychology, 29(3), 309-317.

Stern, P. C. (2000). New environmental theories: toward a coherent theory of environmentally significant behavior. Journal of Social Issues, 56(3), 407-424.

Stern, P. C. ve Dietz, T. (1994). The value basis of environmental concern. Journal of Social Issues, 50(3), 65-84. 
Stern, P. C., Dietz, T., Abel, T., Guagnano, G. A. ve Kalof, L. (1999). A value-belief-norm theory of support for social movements: The case of environmentalism. Human Ecology Review, 6(2), 81-97.

Stern, P. C., Dietz, T. ve Guagnano, G. A. (1998). A brief inventory of values. Educational and Psychological Measurement, 58(6), 984-1001.

Şener, A., ve Hazer, O. (2007). Values and sustainable consumption behavior of women: A Turkish sample. Sustainable Development, 16(5), 291-300.

Tatlidil, H. (2002). Uygulamal çok değģskenli istatistiksel analiæ. Ankara: Ziraat Matbaacılık.

Thøgersen, J. ve Grunert-Beckmann, S. C. (1997). Values and attitude formation towards emerging attitude objects: From recycling to general, waste minimizing behavior. Advances in Consumer Research, 24(1), 182-189.

Thøgersen, J. ve Ölander, F. (2002). Human values and the emergence of a sustainable consumption pattern: A panel study. Journal of Economic Psychology, 23(5), 605-630.

\section{EXTENDED ABSTRACT}

The idea of sustainable development, which addresses the idea of meeting the needs of future generations as well as meeting the needs of the future generations, is a very important mission that all societies try to develop, disseminate and systematize. Most environmental problems such as global warming, urban air pollution, water scarcity, environmental noise and loss of biodiversity, which pose a serious threat to sustainability, appear to be based on human behavior (Gardner \& Stern, 2002; Steg \& Vlek, 2009). This situation requires understanding, adoption and sperading of sustainable consumption behaviors of societies. This is possible by investigating and understanding the factors that determine human behavior.

In this context, individual values affect individuals' behaviors related to the whole area of life besides behaviors as consumers (Karalar \& Kirac1, 2010, p. 81).Values are shared criteria or ideas that indicate which social behavior is good, correct and desirable; behavior is known to be the source of inspiration (Özkalp, 2005, p. 100; Dogan, 2002, p. 341). Values and culture are like spectacles that limit our perspective on environmental issues (Schultz et al., 2005, p. 473). It is thought that by better understanding consumer values; it going to understand much more possible to better predict and control consumer behavior.

In this study, In order to understand the effect of value structures such as "universalism", "benevolence", "power", "achievement" and "hedonism" on environmental behavior types for university students; the value structures "Self-transcendence" and "Self-enhancement" value groups in the dimension of individual values, which are the second axis of the scale known as the Schwartz Values Scale; Environmentally conscious consumption behaviors tendencies according to as Conservative consumption, Recycling supporting and Environmental purchasing behaviors are aimed to be classified. In this way, it will be possible to understand how an environmentally conscious consumption behavior of a person whose value attitude is known will show, or in which value structures university students whose environmentalist behavior tendencies are known.

In the literature, there are many definitions of value. Kluckhohn (1951) defines values as not in desires but in desirable. in other words, it is not just what we want but as things which we feel is right and appropriate for ourselves and others. Rokeach (1973) has defined values as guiding principles, important life goals or standards, and assumed that they identified social behaviors and ideologies. Schwartz and Bilsky (1987) define values as beliefs related to the individual's behaviors in achieving their goals, and also state that values can be graded according to their importance. Schwartz $(1992,1994)$ also states that values provide information about individuals, groups, and societies. It can be concluded that values are not only factors that differentiate individuals from other individuals, but also different groups and societies from other groups and societies.

Values are beliefs related to one's feelings. According to a certain standard, directs behavior to achieve the desired goals, values are principles that lead to relatively important behavior, (Schwartz, 2009). Values are formed in the development process of the individual (Evans, Jamal and Foxall, 2006, p. 22). In the formation of the values of individuals, the values of the society they live in, that is, cultural values, are also effective (Hofstede, cited in 1980 Özgür, 2013, p. 46). Determining values from childhood will help to estimate the values that children have in later years. In other words, the determination of values from the early years will allow the direction of the change in value in the following years to be seen (Kapikiran \& Gündoğan, 2016, p. 125). 
In this study, since SVS scale related to Schwartz's value theory is used, information about this theory is included. Schwartz and Bilsky $(1987 ; 1990)$ took the first steps of Rokeach's attempt to develop a list of values, using 36 values in the value list. Later, in a study conducted in 1992, Schwartz developed Rokeach's list of 36 values and collected 56 values, which are thought to be universal, in 10 groups of values. Furthermore, Schwartz (1992) divided the conflicting values into two dimensions: Opennes to change / Conservation and Self-transcendence /Self-enhancement

Knowing and understanding the consumer's preferences of consumption; to be understood environmental issues are important issues that the effects of environmental problems are should be known and should be considered. Although it is understood that sustainable consumption behavior of certain value types is related to environmental behaviors and consumption behaviors; relationships are not strong; it should not be forgotten that the behavior of an individual who is educated in an individualistic society and who is fond of his taste may not be correct in another society where grouper values are high. Poortinga et al. (2004), using only attitudinal variables such as values, emphasizes that the explanation of all types of environmental behavior may be very limited.

In this study, in order to make the above classification that stated before and to understand which environmental structures differ in which value structures; Multinominal Logistics Logistics Regression analysis has been used. Another aim of this study is to determine which environmental tendency structure is dominant in which value type.

With the help of the findings of this study, in addition to understanding the universal validity of Schwartz's model of values; It is also thought to help to understand the value structures and environmental behaviors of different cultures that will be the subject of cross-cultural comparisons. The universe of the research was applied to 203 valid survey data logistic regression analyzes which were collected from university students in Montana State of the United States of America and the data of the students were collected by volunteer and convenience sampling method. According to obtained the model, the individuals who are in the tendency of Conservative consumption according to the individuals who are in the tendency Environmental purchasing behaviors, about values "universalism" and "success" impact on negative; but value "benevolence" as positive; however, it is understood that individuals who are tendency to recycling support and individuals who have a tendency to save consumption do not differ in terms of their value structures. 